\title{
Conjunctival Carcinoma Clinical TNM Finding v8
}

National Cancer Institute

\section{Source}

National Cancer Institute. Conjunctival Carcinoma Clinical TNM Finding v8. NCI

Thesaurus. Code C140528.

A clinical finding about one or more characteristics of conjunctival carcinoma, following the rules of the TNM AJCC V8 classification system. 